\title{
UK urged to emulate US in linking military research to civilian goals
}

London. Britain's Ministry of Defence(MoD) has been urged to allow its research laboratories to play a far greater role than they can at present in contributing to the nation's economic prosperity, and not merely to its physical defence.

The proposal comes from a committee of the House of Lords, which quotes with approval the way the United States has included that concept of economic security within the broader goals of national security. The committee points, for example, to the Defense Advanced Research Projects Agency (DARPA) - as well as to comparable developments in France - as an example that the United Kingdom could profitably follow.

But the committee also acknowledges that achieving this would require changes in the administration of defence research: these range from revisions in the Treasury rules under which defence laboratories operate, through persuading the Department of Trade and Industry (DTI) to boost funding for joint research projects, to giving the Office of Science and Technology (OST) a more direct say in the planning of the laboratories' research programmes.

Given that each would meet substantial political opposition - the MoD for example, has already fought keenly (and successfully) against the transfer of any control over its resources to the OST - the government is unlikely to accept the broad thrust of the proposals with open arms.

The recommendations are made by the House of Lords's Select Committee on Science and Technology. They are based on an inquiry into the functioning of the Defence Research Agency (DRA), whose report was published this week.

Until recently, MoD laboratories operated under budgets allocated centrally from the ministry. Since 1991, however, those responsible for all research except for that on nuclear, chemical and biological weapons, have operated under the umbrella of the DRA, and have been required to raise their funds through separate contracts with individual 'customers' within the defence establishment.

"In general, we felt that the DRA has been doing a good job," says the committee's chairman, Lord Selborne, pointing in particular to the increased cost-effectiveness of its individual establishments, and the relevance of their work to specific defence needs. But, he adds, "we do not feel that it [the DRA] has had a fair deal from the MoD itself', either in being allowed to plan for its own long-term future -- or in maximizing its potential contribution to the civilian economy.

One problem is the difficulty faced by the DRA as a 'contractor' organization in developing a long-term view of future re-

\section{New faces to head British science}

London. Last week's reshuffle of the British cabinet saw the arrival of a new science minister with the appointment of David Hunt, formerly e mploy m e n t minister, to the position of Chancellor of the Duchy of Lancaster, responsible for the Office of Public Services and Science.

The permanent secretary in the office is Robert Hughes, formerly a parliamentary whip for the Conservative Party (and, before his election to Parliament in 1987, a news editor with the British Broadcasting Corporation).

The fact that Hunt has been given wider-ranging political responsibilities than his predecessor, William Waldegrave - he will, for example, search needs. Indeed, the committee points out that even the DRA, in a corporate plan that is not publicly available, says it is an "illusion" to believe that its business planning can be based on the MoD's long-term costing process.

Selborne points out that several witnesses to the inquiry expressed fears that the DRA will be forced by the need for greater commercial discipline to focus on more shortterm research and development at the expense of its longer-term research. "We accept that these fears may be well-founded," the committee's report says.

Furthermore, requiring the DRA to seek a customer for every activity "does not create an environment in which DRA can readily plan ahead and establish a strong foothold in support of wealth creation beyond the defence sector".

Finally, the committee suggests that the OST should be given far greater power to ensure that the MoD plays an active role in allowing the DRA's research facilities to be used for the broader goal of wealth creation - and not confined, as at present, to meeting the technological needs of the armed forces.

One solution, it suggests, could be to give OST (as well as the DTI) part ownership of DRA. Another would be to give the government's chief scientific adviser the authority "to expose any links which impeded closer links between civil and military science and technology".

Defence administrators, like other civil servants, are fiercely protective of their turf, and are unlikely to view either proposal with much enthusiasm. But Selborne points out that, whatever reservations they may have, the proposals are in line with the main thrust of last year's white paper on science, Realizing our Potential.

Indeed, Selborne implies that, unless the OST is able to flex its muscles in this or similar ways, it will have failed to meet expectations raised by the white paper that the government is genuinely committed to focusing the nation's whole research base on the twin needs of wealth creation and improving the quality of life.

Under the new arrangements for defence research announced last week, the DRA will become part of a new Defence Science Technology Agency. The government also says that it intends to separate 'corporate' and 'contract' research, with the implication that the first of these will include responsibility for meeting long-term scientific and technical needs. But it has also announced that a key goal will be to reduce spending on research in both categories.

David Dickson 